\title{
Effect of rumen protected choline supplementation on milk production and composition of lactating Friesian cows
}

M Mohsen, H Gaafar, M Khalafallah, A Shitta, A Elsheikh

Animal Production Research Institute, Kafrelsheikh, Egypt

Email: gaafar356@hotmail.com

Introduction: Rumen-protected choline (RPC) products have been fed to periparturient dairy cows to increase the supply of choline to the small intestine with the goal of increasing milk or component yields or alleviating the development of fatty liver syndrome (Hartwell et al., 2000; Piepenbrink and Overton, 2003; Pinotti et al., 2003; Overton and Waldron, 2004). Increasing the postruminal supply of choline by an infusion of choline into the abomasum has increased milk production and milk fat yield (Erdman and Sharma 1991).

Materials and methods Twelve lactating Friesian cows were used in a complete switch-back design (Lucas, 1956). The cows were fed the basal ration consisted on DM basis from $40 \%$ concentrate feed mixture $+40 \%$ fresh berseem $+20 \%$ rice straw without supplement $\left(\mathrm{G}_{1}\right)$ or supplemented with 15 and $30 \mathrm{~g}$ choline chloride / head / day for $\mathrm{G}_{2}$ and $\mathrm{G}_{3}$, respectively.

Results Results in Table (1) showed that the digestibility coefficients of all nutrients and nutritive values increased significantly $(\mathrm{P}<0.05)$ with rumen protected choline supplementation. Rumen protected choline supplementation increased significantly $(\mathrm{P}<0.05)$ the intake of TDN and DCP. The $\mathrm{pH}$ values and $\mathrm{NH}_{3}-\mathrm{N}$ concentration deceased significantly $(\mathrm{P}<0.05)$ and TVFA's concentration increased significantly $(\mathrm{P}<0.05)$ in rumen liquor with rumen protected choline supplementation. Rumen protected choline supplementation led to significant decrease $(\mathrm{P}<0.05)$ in the concentration of plasma cholesterol and significant increase $(\mathrm{P}<0.05)$ in triglycerides. However, the concentrations of glucose, total protein, albumin, globulin and urea-N and the activity of AST and ALT were nearly similar for the different groups. Rumen protected choline supplementation led to significant increase $(\mathrm{P}<0.05)$ in actual milk and $4 \%$ FCM yield. The contents of fat and total solids (TS) and the yield of all milk constituents except ash increased significantly $(\mathrm{P}<0.05)$ with rumen protected choline supplementation. Results in Table (2) revealed that rumen protected choline supplementation improved feed conversion, which led to significant decrease $(\mathrm{P}<0.05)$ in the quantities of DM, TDN and DCP per kg 4\% FCM. Average daily feed cost were nearly similar for the different groups. While, the feed cost per one $\mathrm{kg} 4 \% \mathrm{FCM}$ decreased significantly $(\mathrm{P}<0.05)$, the average income of milk yield increased significantly $(\mathrm{P}<0.05)$ with rumen protected choline supplementation.

Table 1 Effect of rumen protected choline supplementation on nutritive values, feed intake, rumen parameters, milk yield and composition.

\begin{tabular}{|c|c|c|c|c|c|c|c|c|c|c|c|c|c|c|}
\hline \multirow{2}{*}{ Item } & \multicolumn{2}{|c|}{ Nutritive values $\%$} & \multicolumn{3}{|c|}{ Intake kg/day } & \multicolumn{3}{|c|}{ Rumen parameters } & \multicolumn{3}{|c|}{ Milk yield kg/day } & \multicolumn{3}{|c|}{ Milk composition $\%$} \\
\hline & $\mathrm{TD}$ & DCP & DM & TDN & $\mathrm{CP}$ & $\mathrm{pH}$ & $\mathrm{NH}$ & 1 & & FCM & Fat & Prot & $\mathrm{La}$ & $\Gamma \mathrm{S}$ \\
\hline on & $60.87^{b}$ & $8.57^{b}$ & 16.08 & $9.79^{b}$ & $1.38^{\mathrm{b}}$ & $6.95^{\mathrm{a}}$ & $14.81^{b}$ & $18.95^{\mathrm{a}}$ & $15.22^{b}$ & $14.22^{b}$ & $3.56^{\mathrm{b}}$ & 3.12 & 4.39 & $11.78^{b}$ \\
\hline $15 q$ & $63.98^{\mathrm{a}}$ & $8.96^{\mathrm{a}}$ & 16.17 & $10.35^{\mathrm{a}}$ & $1.45^{\mathrm{a}}$ & $6.72^{\mathrm{b}}$ & $17.14^{\mathrm{a}}$ & $16.63^{\mathrm{b}}$ & $16.54^{\mathrm{a}}$ & $15.77^{\mathrm{a}}$ & $3.69^{\mathrm{a}}$ & 3. & 4.39 & $11.94^{\mathrm{a}}$ \\
\hline $30 \mathrm{~g}$ RPC & $64.62^{\mathrm{a}}$ & $9.05^{\mathrm{a}}$ & 16.20 & $10.47^{\mathrm{a}}$ & $1.47^{\mathrm{a}}$ & $6.67^{\mathrm{b}}$ & $17.43^{\mathrm{a}}$ & $16.25^{\mathrm{b}}$ & $17.46^{\mathrm{a}}$ & $16.82^{\mathrm{a}}$ & $3.75^{\mathrm{a}}$ & 3.16 & 4.43 & $12.05^{\mathrm{a}}$ \\
\hline
\end{tabular}

a, b: Values and means in the same row with different superscripts differ significantly at $5 \%$ level.

Table 2 Effect of rumen protected choline supplementation on feed conversion and economic efficiency.

\begin{tabular}{llllllll}
\hline \multirow{2}{*}{ Item } & \multicolumn{3}{c}{ Feed conversion kg / kg FCM } & \multicolumn{4}{c}{ Economic efficiency LE } \\
\cline { 2 - 8 } & DM & TDN & DCP & Cost & Cost/ kg FCM & Income & Income \% \\
\hline control & $1.14^{\mathrm{a}}$ & $0.69^{\mathrm{a}}$ & $0.098^{\mathrm{a}}$ & 19.18 & $1.36^{\mathrm{a}}$ & $28.44^{\mathrm{b}}$ & $100.00^{\mathrm{c}}$ \\
$15 \mathrm{~g} \mathrm{RPC}$ & $1.03^{\mathrm{b}}$ & $0.66^{\mathrm{ab}}$ & $0.093^{\mathrm{ab}}$ & 19.37 & $1.24^{\mathrm{b}}$ & $31.55^{\mathrm{a}}$ & $110.94^{\mathrm{b}}$ \\
$30 \mathrm{~g} \mathrm{RPC}$ & $0.97^{\mathrm{b}}$ & $0.62^{\mathrm{b}}$ & $0.088^{\mathrm{b}}$ & 19.50 & $1.17^{\mathrm{b}}$ & $33.64^{\mathrm{a}}$ & $118.28^{\mathrm{a}}$ \\
\hline
\end{tabular}

a, b: Values and means in the same row with different superscripts differ significantly at $5 \%$ level.

Conclusions It could be concluded that rumen protected choline supplementation to lactating Friesian cows improved nutrients digestibility, milk yield and composition, feed conversion and economic efficiency.

\section{References}

Erdman, R.A. and B.K. Sharma 1991. Effect of dietary rumen protected choline in lactating dairy cows. Journal of Dairy Science, 74, 1641.

Hartwell, J.R.; M.J. Cecava and S.S. Donkin 2000. Impact of rumen undegradable protein and rumen-protected choline on intake, peripartum liver triglyceride, plasma metabolites and milk production in transition dairy cows. Journal of Dairy Science, 83, 2907.

Overton T.R. and M.R. Waldron 2004. Nutritional management of transition dairy cows: strategies to optimize metabolic health, Journal of Dairy Science, 87, 105.

Piepenbrink, M.S. and T.R. Overton 2003. Liver metabolism and production of cows fed increasing amounts of rumenprotected choline during the periparturient period. Journal of Dairy Science, 86, 1722.

Pinotti, L.; A. Baldi; I. Politis; R. Rebucci; L. Sangalli and V. Dell'Orto 2003. Rumen-protected choline administration to transition cows: Effect on milk production and vitamin E status. Journal of Veterinary Medicine A., 50, 18. 